\title{
Genetic approach in amyotrophic lateral sclerosis
}

Iván Cervantes-Aragón, ${ }^{1}$ Sergio Alberto Ramírez-García, ${ }^{2,3}$ Luz Margarita Baltazar-Rodríguez, ${ }^{3}$

Diana García-Cruz ${ }^{*}$, and Gema Castañeda-Cisneros ${ }^{5}$

${ }^{1}$ Universidad Guadalajara Lamar, Guadalajara, Jalisco; ${ }^{2}$ Sistema de Universidades de Oaxaca, Institute of Research on Public Health, Universidad de la Sierra Sur, Oaxaca; ${ }^{3}$ Universidad de Colima, Faculty of Medicine, Colima; ${ }^{4}$ Universidad de Guadalajara, University Center of Health Sciences, Department of Molecular Biology and Genomics, Jalisco; ${ }^{5}$ Instituto Mexicano del Seguro Social, Centro Médico Nacional de Occidente, Department of Neurosurgery, Jalisco. Mexico

\begin{abstract}
\end{abstract}
The superoxide dismutase type 1 (SOD1) gene is the first responsible gene mapped in amyotrophic lateral sclerosis type 1 (ALS1), and it codes for the enzyme SOD1, the function of which is to protect against damage mediated by free radicals deriving from oxygen. Its pathophysiological mechanism in ALS1 is related to ischemia. Several molecular studies of the SOD1 gene show that point mutations are the most frequent. The most common mutations in familial cases are p.A4V, p.I113Y, p.G37R, p.D90A and p.E100G, which account for more than $80 \%$ of cases, although intronic mutations have also been described as responsible for ALS1. Sporadic cases are explained by mutations in other genes such as SETX and C9orf72. ALS1 is a complex disease with genetic heterogeneity. On the other hand, familial and sporadic cases have a different etiology, which is explained by molecular heterogeneity and multiple pathogenic mechanisms that lead to ALS1; oxidative stress and ischemia are not the only cause. In Mexico, ALS molecular genetics studies are scarce. Clinical studies show an increase in cytokines such as adipsin in cerebrospinal fluid.

KEY WORDS: Familial motor neuron disease. Muscle atrophy. Superoxide dismutase 1.

\section{Introduction}

Amyotrophic lateral sclerosis (ALS) is a lethal, progressive neurodegenerative disease that affects upper and lower motor neurons. ${ }^{1-2}$ Its prevalence in Mexico ranges from 5000 to 7000 patients according to Martínez et al. In France, it is estimated at 2.5 per 100,000 population. ${ }^{3}$ The age of onset is approximately 47.5 years, with survival of up to 58.9 months after diagnosis. Otero et al. reported that ALS accounts for more than $90 \%$ of cases of motor neuron diseases in Mexico, with the phenotype including signs of upper or lower motor neuron. ${ }^{1}$

\section{Genetic and molecular epidemiology}

ALS occurs sporadically (SALS) in 90 to $95 \%$ of cases and family-wise (FALS) in 5 to $10 \%$. Sporadic forms are more often observed outside the European continent. $^{1-3}$ FALS forms are associated with a large number of pleiotropic genes (Table 1), which results in clinical and pathological phenotypes overlap. ఫifferent inheritance patterns have also been described. ${ }^{3}$ The genes most frequently associated with FALS are SOD1 Tau. ${ }^{4,5}$ Mutations in the SOD1 gene explain $2 \%$ of cases affected by SALS, out of which approximately $10 \%$ are inherited as a dominant autosomal pattern with high penetrance after the sixth decade. Clinical phenotype is similar in FALS and SALS cases. ${ }^{-6}$ It should be noted that Scandinavians' p.D90A mutation is transmitted with a recessive pattern ${ }^{10}$ (Table 1)

SOD1 classical mutations in ALS are p.G37T, p.L38V, p.G41S, p.G41D, p.H43R, p.G85R, p.G.93C, p.G93A, p.E100G, p.L106V and p. I113Y, which produce changes in SOD1, thus decreasing enzymatic activity. ${ }^{\text {In }}$ an Italian population, the p.G12R, p.G $\overline{41}$ S,
Correspondence:

*Diana García-Cruz

E-mail: dianagarcr@hotmail.com
Date of reception: 13-12-2018

Date of acceptance: 21-02-2019

DOI: 10.24875/GMM.M20000335
Gac Med Mex. 2019;155:475-482

Contents available at PubMed

www.gacetamedicademexico.com

0016-3813/@ 2019 Academia Nacional de Medicina de México, A.C.. Published by Permanyer. This is an open access article under the CC BY-NC-ND license (http://creativecommons.org/licenses/by-nc-nd/4.0/). 
Gaceta Médica de México. 2020;155

Table 1. Types of ALS according to the involved gene and its inheritance pattern

\begin{tabular}{|c|c|c|c|c|c|c|c|}
\hline Type & Symbol & Gene & Locus & FALS & SALS & Inheritance & $\stackrel{2}{=}$ \\
\hline ALS 1 & SOD1 & $\mathrm{Cu} / \mathrm{Zn}$ superoxide dismutase 1 & $21 q 22.11$ & Yes & Yes & $A D$ and $A R$ & $\stackrel{\gtrless}{c}$ \\
\hline ALS 2 & ALS2 & Alsin 2 & $2 q 33.2$ & Yes & No & AR & $\varepsilon$ \\
\hline ALS 3 & ALS3 & Alsin 3 & $18 q 21$ & Yes & No & $A D$ & 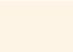 \\
\hline ALS 4 & SETX & Senataxin & $9 q 34.13$ & Yes & Yes & $A D$ & (E) \\
\hline ALS 5 & SPAST & Spastin & $2 p 24$ & Yes & Yes & AR & さ \\
\hline ALS 6 & FUS & t-derived gene $(12 ; 16)$ & $16 \mathrm{p} 11.2$ & Yes & Yes & $A D$ & 응 \\
\hline ALS 7 & $A L S 7$ & Alsin 7 & $20 \mathrm{p} 13$ & Yes & No & $A D$ & 음 \\
\hline ALS 8 & VAPB & $\begin{array}{l}\text { B-protein associated with vesicle membrane-associated } \\
\text { protein }\end{array}$ & $20 q 13.33$ & Yes & No & $A D$ & $\frac{c}{+}$ \\
\hline ALS 9 & ANG & Angiogenin & $14 q 11.1$ & Yes & Yes & $A D$ & $\bar{c}$ \\
\hline ALS 10 & TARDBP & TAR DNA-binding protein & 1p36.22 & Yes & Yes & $A D$ & $\frac{\varkappa}{E}$ \\
\hline ALS 11 & FIG4 & $\begin{array}{l}\text { Homologous to FIG4, SCA1 lipid } \\
\text { phosphatase-containing domain }\end{array}$ & $6 q 21$ & Yes & Yes & $A D$ & $\frac{1}{\frac{1}{2}}$ \\
\hline ALS 12 & OPTN & Optineurin & $10 p 13$ & Yes & Yes & $A D$ and $A R$ & $\stackrel{ \pm}{ \pm}$ \\
\hline ALS 13 & ATXN2 & Ataxin 2 & $12 q 23-24.1$ & No & Yes & --- & $\overline{3}$ \\
\hline ALS 14 & VCP & Valiosin-containing protein & $9 p 13$ & Yes & No & $A D$ & 은 \\
\hline ALS 15 & UBQLN2 & Ubiquitin 2 & Xp11.21 & Yes & No & Dominant X-1 & -linked \\
\hline ALS 16 & SIGMAR1 & Non-opioid sigma 1 intracellular receptor & $9 p 13$ & Yes & No & $A R$ & \pm \\
\hline ALS 17 & CHMP28 & --- & $3 p 11.2$ & No & Yes & --- & 으 \\
\hline ALS 18 & PFN1 & Profilin 1 & $17 \mathrm{p} 13.3$ & No & Yes & --- & $\overline{3}$ \\
\hline ALS 19 & ERBB4 & Viral avian erythroblastic leukemia oncogene homolog & $2 q 34$ & Yes & No & $A D$ & ठ \\
\hline ALS 20 & HNRNPA1 & Heterogeneous nuclear ribonucleoprotein A1 & $12 q 13.13$ & Yes & Yes & $A D$ and $A R$ & $\frac{\hat{\alpha}}{0}$ \\
\hline ALS 21 & MATR3 & Matrin 3 & $5 q 31.2$ & Yes & No & $A D$ & 일 \\
\hline ALS-DFT2 & $\mathrm{CHCHD10}$ & $\begin{array}{l}\text { Coiled-Coil-Helix-Coiled-Coil-Helix } \\
\text { Domain-Containing Protein } 10\end{array}$ & 9q21-q22 & Yes & No & $A D$ & $\frac{c}{\frac{c}{2}}$ \\
\hline ALS-DFT1 & C9orf7 2 & Chromosome 9 open reading framework 72 & $9 p 21.2$ & Yes & Yes & $A D$ & ర్ \\
\hline Risk & UNC13A & Caenorhabditis eleganss A homolog & $19 p 13.11$ & No & Yes & & $\frac{0}{0}$ \\
\hline--- & $D A O$ & D-amino acid oxidase & $12 q 24$ & Yes & No & $A D$ & 인 \\
\hline-- & DCTN1 & Dinactin & $2 p 13$ & Yes & Yes & $A D$ & $\stackrel{0}{0}$ \\
\hline--- & NEFH & Neurofilament constitutive 200-kDA heavy chain & $22 q 12.1$ & Yes & Yes & $A D$ & $\stackrel{0}{\lambda}$ \\
\hline-- & PRPH & Peripherin & $12 q 12$ & No & Yes & --- & $\varepsilon$ \\
\hline--- & SQSTM1 & Sequestrosome 1 & $5 q 35$ & Yes & Yes & $A D$ & $\frac{1}{1}$ \\
\hline--- & TAF15 & TATA box binding protein-associated factor & $17 q 11.1-q 11.2$ & Yes & No & $A D$ & . \\
\hline--- & SPAST & Spastin & $2 p 24$ & No & Yes & --- & $\frac{0}{2}$ \\
\hline--- & ELP3 & $\begin{array}{l}\text { Homolog elongation protein } 3 \text { (Saccharomyces } \\
\text { cerevisiae) }\end{array}$ & $8 p 21.1$ & No & Yes & --- & $\frac{n}{\frac{n}{x}}$ \\
\hline--- & LMNB1 & Laminin B1 & $5 q 23.2$ & Yes & No & $A D$ & 0 \\
\hline \multicolumn{8}{|c|}{ 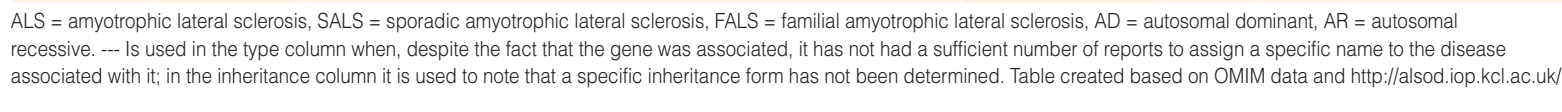 } \\
\hline
\end{tabular}


p.L114F and p.D90A mutations were found in seven out of 39 patients with atypical-phenotype FALS. In addition, a synonymous p.S59S variant was identified in a patient with ALS. ${ }^{7}$

In another case series, nt34A>C intron 3 polymorphism was found in 17 out of 264 patients (6.4\%), and the IVS3 + 62 T> C variant was identified in one FALS patient. Total frequency of SOD1 gene mutations $(17.9 \%)$ in FALS cases was comparable to that found in other studies, with a similar sample size of ALS cases. Among the FALS cases, the most common mutation was p.G41S.11

In another cross-sectional Italian population cohort, eight out of 38 patients (21\%) with FALS and five out of $175(3 \%)$ with SALS had nonsense mutations in the SOD1 gene. Two additional mutations were identified, one in exon 4 (p.L84F) in a familial case and the second in exon 3 (p.G72S) in a sporadic patient. ${ }^{12}$

\section{The role of the SOD1 enzyme}

The SOD1 gene has its locus at 21q22.11, it has a length of 9310 base pairs (bp) and is composed of five exons; it encodes the superoxide dismutase (SOD1) enzyme. This protein has 153 amino acid residues with a weight of $16 \mathrm{kDa}^{13}$ and oxidoreductase and peroxidase activities. Its quaternary structure is formed by barrel-shaped beta strands arranged in a Greek key motif. ${ }^{14}$ Each homodimer constitutes a unit called A, B, C, D or E and has the capacity to associate with four other units, reaching a configuration similar to a "dog femoral bone"; in turn, these structures tend to group forming asymmetric units, which generate a structure that resembles a honeycomb. ${ }^{14}$

The SOD1 enzyme is cytoplasmic, and catalyzes the conversion of superoxide with nitric oxide (NO) to the peroxidized anion (ONOO-) form, which generates $\mathrm{HO}$ and $\mathrm{NO}_{2}$ toxic radicals. ${ }^{14-16}$ This mechanism might induce neurodegeneration due to free radical accumulation, causing cell death. ${ }^{7}$

Through immunohistochemistry, SOD1 has been shown to be abundantly distributed in motor neurons, interneurons and sensory neurons in the spinal cord, ${ }^{17}$ with a punctate pattern in the motor and sensory portions of the cranial nerve nuclei, the soma, as well as in proximal dendrites and terminal axons in unaffected individuals:18 it has been diffusely found in the cortex, hippocampus and amygdala. ${ }^{19}$ On the other hand, a more abundant expression of SOD1 has been demonstrated in patients affected by ALS. These evidences strongly support the gain-of-function hypothesis with toxic effect rather than haploinsufficiency. ${ }^{18,20}$

\section{Mutations in the SOD1 gene}

Most mutations reported in SOD1 are nucleotide changes with sense or intron reading frame shifts. ${ }^{-3}$ The effect of enzyme activity percentage is a poorly studied field, which limits genotype-phenotype correlation determination. Among the largest studies that have reported the frequency of mutations in the SQDD1 gene is the cohort of 2045 non-Hispanic whitegatients with FALS and SALS, among which SOD 1 mutations were found in 148 cases. The most prevalent mutations associated with the disease in the SODD1 gene were p.A4V, in $41 \%$ of patients, p.lle113Tre in $16 \%$ and intron mutations in $11 \%$. Sixteen exon $\frac{\text { m }}{4}$ tations were found (p.K8V, p.F20C, p.Q22L, p.H48R, p.T54R, p.S59I, p.V87A, T88DTAD, p.A89T, p.V97M, p.S105DSL, p. V118L, p.D124G, p.G141X, p.G147R and $p .1151 S$, which correspond to a frequency of 10.81 $\%$. In $2.7 \%$ of cases with SALS, four patients were detected with the following mutations: p.G37R $\mathrm{R}_{\mathrm{e}}^{\mathrm{C}}$. D90A and p.E100G. ${ }^{21}$

In another cohort of non-Hispanic white subjects with FALS, the p.A4V mutation in exon 1 was the most common (32\%). On the other hand, the p. G37 $R$ p.G93A, p.E100G and p.I113Y mutations had a frequency of $8 \%$. The study of molecular coupling (docking) of these variants reveals the alteration of the interactions for the contact of the doublets and the beta barrel dimer. The red blood cells of the heterrozygous index cases had less than $50 \%$ activity, which consistent with a structurally defective SOD dimer. ${ }^{22}$

In clinical practice, genotype-phenotype correlation studies are important (Table 2); for example, in a FALS cohort in an Asian Japanese population, four different sense mutations were reported in exons 2, 4 and $\frac{0}{5}$ of the SOD1 gene in five families: p.H46R, p.L84V, p.I104F and p.V148I. Patients with the p.H46R mutation showed a benign clinical course and stereotyped progression of muscle weakness and leg atrophy. p.L84V carriers have a very similar clinical course of disease, with the age of onset being earlier in males than in females. Patients with p.I104F showed wide ranges of age of onset and duration, with ophthalmoparesis and sensory involvement in one patient. Those with the p.V148I mutation showed an earlier age at onset and first variable symptoms within the family. Although the LMN sign was evident in all cases, hyperreflexia varied between patients with different 
Gaceta Médica de México. 2020;155

Table 2. Genotype-phenotype correlation for mutations in SOD1

\begin{tabular}{|c|c|c|c|c|c|c|c|}
\hline Type & $\begin{array}{l}\text { Type of } \\
\text { mutation }\end{array}$ & Frequency (\%) & Affected (n) & Clinical phenotype & $\begin{array}{l}\text { Enzyme } \\
\text { activity \% }\end{array}$ & Population & Referenc \\
\hline SALS & p.E21K & 1.5 & $1 / 67$ & Definitive diagnosis & Not reported & $\begin{array}{l}\text { European, } \\
\text { Scottish }\end{array}$ & 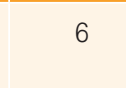 \\
\hline SALS & p.1113Y & 87 & $20 / 23$ & Definitive diagnosis & Not reported & $\begin{array}{l}\text { Non-Hispanic } \\
\text { White }\end{array}$ & $8_{0}^{\circ}$ \\
\hline SALS & IVS3+34 A >C & 5.3 & $14 / 264$ & Definitive diagnosis & Not reported & European, Italian & $11 \frac{2}{\pi}$ \\
\hline SALS & p.S59S & 0.4 & $1 / 264$ & Definitive diagnosis & Not reported & European, Italian & $11 \frac{\sqrt{2}}{2}$ \\
\hline SALS & p.G72S & 2.6 & $1 / 38$ & Definitive diagnosis & Not reported & $\begin{array}{l}\text { European, } \\
\text { English }\end{array}$ & $12 \frac{12}{20}$ \\
\hline SALS & p.G37R & 1.4 & $2 / 148$ & Definitive diagnosis & Not reported & $\begin{array}{l}\text { Non-Hispanic } \\
\text { White }\end{array}$ & 22 \\
\hline SALS & p.D90A & 0.7 & $1 / 148$ & Definitive diagnosis & Not reported & $\begin{array}{l}\text { Non-Hispanic } \\
\text { White }\end{array}$ & $22 \frac{0}{2}$ \\
\hline SALS & p.A4V & 7.7 & $1 / 13$ & Definitive diagnosis & Not reported & $\begin{array}{l}\text { Caucasian, } \\
\text { Canadian }\end{array}$ & 24 \\
\hline SALS & p.G72C & 7.7 & $1 / 13$ & Definitive diagnosis & Not reported & $\begin{array}{l}\text { Caucasian, } \\
\text { Canadian }\end{array}$ & 24 \\
\hline SALS & p.D76Y & 7.7 & $1 / 13$ & Definitive diagnosis & Not reported & $\begin{array}{l}\text { Caucasian, } \\
\text { Canadian }\end{array}$ & $24 \frac{0}{-3}$ \\
\hline SALS & p.D90A & 7.7 & $1 / 13$ & Definitive diagnosis & Not reported & $\begin{array}{l}\text { Caucasian, } \\
\text { Canadian }\end{array}$ & 240 \\
\hline FALS & p.D90A & 7.7 & $1 / 13$ & Definitive diagnosis & Not reported & $\begin{array}{l}\text { Caucasian, } \\
\text { Canadian }\end{array}$ & $240^{\circ}$ \\
\hline FALS & p.D90A & 7.7 & $1 / 39$ & Atypical phenotype & Not reported & European, Italian & $11^{>}$ \\
\hline SALS & p.C111Y & 7.7 & $1 / 13$ & Definitive diagnosis & Not reported & $\begin{array}{l}\text { Caucasian, } \\
\text { Canadian }\end{array}$ & $24 \frac{2}{2}$ \\
\hline SALS & p.1113Y & 7.7 & $1 / 13$ & Definitive diagnosis & Not reported & $\begin{array}{l}\text { Caucasian, } \\
\text { Canadian }\end{array}$ & $\begin{aligned} 240 \\
0 \\
0\end{aligned}$ \\
\hline FALS & p.1113Y & 13 & 9/67 & Definitive diagnosis & Not reported & $\begin{array}{l}\text { European, } \\
\text { Scottish }\end{array}$ & $6 \frac{2}{0}$ \\
\hline FALS & p.1113Y & 8 & 2/25 & $\begin{array}{l}\text { Severe progressive } \\
\text { neurogenic muscular atrophy }\end{array}$ & Lower than 50\% & $\begin{array}{l}\text { Non-Hispanic } \\
\text { White }\end{array}$ & $\frac{220}{\frac{20}{0}}$ \\
\hline FALS & p.1113Y & 16 & $24 / 148$ & Definitive diagnosis & Not reported & $\begin{array}{l}\text { Non-Hispanic } \\
\text { White }\end{array}$ & $21 \frac{10}{0}$ \\
\hline FALS & p.G93R & 1.5 & $1 / 67$ & Definitive diagnosis & Not reported & $\begin{array}{l}\text { European, } \\
\text { Scottish }\end{array}$ & $\frac{60}{\lambda}$ \\
\hline FALS & p.E100G & 1.5 & $1 / 67$ & Definitive diagnosis & Not reported & $\begin{array}{l}\text { European, } \\
\text { Scottish }\end{array}$ & $6 \frac{\varepsilon}{c}$ \\
\hline FALS & p.G12R & 7.7 & $1 / 39$ & $\begin{array}{l}\text { Slowly progressive disease } \\
\text { course }\end{array}$ & Not reported & European, Italian & 11. \\
\hline FALS & p.L114F & 7.7 & $1 / 39$ & Slowly progressive course & Not reported & European, Italian & 110 \\
\hline FALS & IVS3+62 T & 0.4 & $1 / 14$ & Definitive diagnosis & Not reported & European, Italian & 11 \\
\hline FALS & p.G72C & 7.7 & $1 / 13$ & Definitive diagnosis & Not reported & $\begin{array}{l}\text { Caucasian, } \\
\text { Canadian }\end{array}$ & 240 \\
\hline
\end{tabular}


Cervantes-Aragón I, et al.: SOD1 in amyotrophic lateral scierosss

Table 2. Genotype-phenotype correlation for mutations in SOD1 (Continued)

\begin{tabular}{|c|c|c|c|c|c|c|c|}
\hline Type & $\begin{array}{l}\text { Type of } \\
\text { mutation }\end{array}$ & Frequency (\%) & Affected (n) & Clinical phenotype & $\begin{array}{l}\text { Enzyme } \\
\text { activity \% }\end{array}$ & Population & Reference \\
\hline FALS & p.D76Y & 7.7 & $1 / 13$ & Definitive diagnosis & Not reported & $\begin{array}{l}\text { Caucasian, } \\
\text { Canadian }\end{array}$ & \\
\hline FALS & p.C111Y & 7.7 & $1 / 13$ & Definitive diagnosis & Not reported & $\begin{array}{l}\text { Caucasian, } \\
\text { Canadian }\end{array}$ & \\
\hline FALS & p.G37R & 8 & $2 / 25$ & $\begin{array}{l}\text { Severe progressive } \\
\text { neurogenic muscular atrophy }\end{array}$ & Lower than $50 \%$ & $\begin{array}{l}\text { Non-Hispanic } \\
\text { White }\end{array}$ & 22" \\
\hline FALS & p.G93A & 8 & $2 / 25$ & $\begin{array}{l}\text { Severe progressive } \\
\text { neurogenic muscular atrophy }\end{array}$ & Lower than $50 \%$ & $\begin{array}{l}\text { Non-Hispanic } \\
\text { White }\end{array}$ & \\
\hline FALS & p.E100G & 8 & $2 / 25$ & $\begin{array}{l}\text { Severe progressive } \\
\text { neurogenic muscular atrophy }\end{array}$ & Lower than $50 \%$ & $\begin{array}{l}\text { Non-Hispanic } \\
\text { White }\end{array}$ & $\frac{22}{4}$ \\
\hline FALS & p.L84V & 10 & $3 / 30$ & Early age of onset & Lower than $50 \%$ & Asian Japanese & \\
\hline FALS & p.H46R & 6.7 & $2 / 30$ & Benign clinical course & Lower than $50 \%$ & Asian Japanese & \\
\hline FALS & p. $1104 \mathrm{~F}$ & 6.7 & $2 / 30$ & $\begin{array}{l}\text { Ophthalmoparesis and } \\
\text { sensorial involvement }\end{array}$ & $\begin{array}{l}\text { Severe } \\
\text { reduction, lower } \\
\text { than } 10 \%\end{array}$ & Asian Japanese & $\frac{23 \frac{2}{c}}{\frac{2}{4}}$ \\
\hline FALS & p.A4V & 15.28 & $2 / 13$ & Definitive diagnosis & Not reported & $\begin{array}{l}\text { Caucasian, } \\
\text { Canadian }\end{array}$ & 24 \\
\hline FALS & p.I113Y & 13 & $3 / 23$ & Definitive diagnosis & Not reported & $\begin{array}{l}\text { Non-Hispanic } \\
\text { White }\end{array}$ & $8 \frac{0}{\frac{2}{2}}$ \\
\hline FALS & IVS3+34 A > C & 1.14 & $3 / 264$ & Definitive diagnosis & Not reported & European, Italian & $1 \leftleftarrows$ \\
\hline FALS & p.G41S & 30.8 & $4 / 39$ & $\begin{array}{l}\text { Rapidly progressive course } \\
\text { with severe cognitive } \\
\text { impairment }\end{array}$ & Not reported & European, Italian & $\frac{110}{\frac{10}{+\frac{3}{3}}}$ \\
\hline FALS & p.V148I & 13.3 & $4 / 30$ & Early onset & Lower than $10 \%$ & Asian Japanese & 23 읻 \\
\hline FALS & p.A4V & 32 & $8 / 25$ & $\begin{array}{l}\text { Severe progressive } \\
\text { neurogenic muscular atrophy }\end{array}$ & Lower than $50 \%$ & $\begin{array}{l}\text { Non-Hispanic } \\
\text { White }\end{array}$ & 220 \\
\hline FALS & p.G41S & 100 & $9 / 9$ & $\begin{array}{l}\text { Severe phenotype, rapidly } \\
\text { progressive }\end{array}$ & Not reported & European, Italian & $\frac{260}{c}$ \\
\hline FALS & p.D90A & 38.5 & $12 / 60$ & Definitive diagnosis & Not reported & Asian, Iranian & $25 \overline{0}$ \\
\hline FALS & p.L84F & 2.6 & $1 / 38$ & Definitive diagnosis & Not reported & $\begin{array}{l}\text { European, } \\
\text { English }\end{array}$ & $\frac{120}{\frac{1}{2}}$ \\
\hline FALS & p.A4V & 41 & $61 / 148$ & Definitive diagnosis & Lower than $10 \%$ & $\begin{array}{l}\text { Non-Hispanic } \\
\text { White }\end{array}$ & $21 \frac{0}{0}$ \\
\hline \multicolumn{7}{|c|}{ SALS = sporadic amyotrophic lateral sclerosis, FALS = familial amyotrophic lateral sclerosis. } & $\frac{\searrow}{\text { बे }}$ \\
\hline
\end{tabular}

mutations. ${ }^{23}$ Bulbar paralysis was common in p.I104F carriers, but not in those with p.H46R. Red blood cell SOD1 activity was severely reduced with p.I104F and p.V148I, but slightly reduced with p.H46R. ${ }^{24}$

Another study with this approach in 254 patients with FALS and SALS in the province of British Columbia, Canada, showed, in 13 patients (5.1\%), the p.A4V, p.G72C, p.D76Y, p.D90A, p.C111Y and p.I113T mutations in SOD1, both in FALS and SALS. There were clinical discordances even between patients with the same mutation. This supports the hypothesis that
ALS is a heterogeneous disorder where genetics, the environment and aging interrelate to form the final clinical phenotype. ${ }^{24}$

In an Asian Iranian cohort of 60 patients with ALS: four families), SOD1 mutations were found in $11.7 \%, 38.5 \%$ of FALS subjects and in $4.25 \%$ of SALS cases, the screening identified p.D90A homozygous in all retated families. Haplotype analysis suggests that Iranianopatients might share a common founder with the famous recessive Scandinavian p.D90A allele. Other mutations identified were p.L84F, p.A4Y and p.I113Y. ${ }^{25}$ In an Italian 


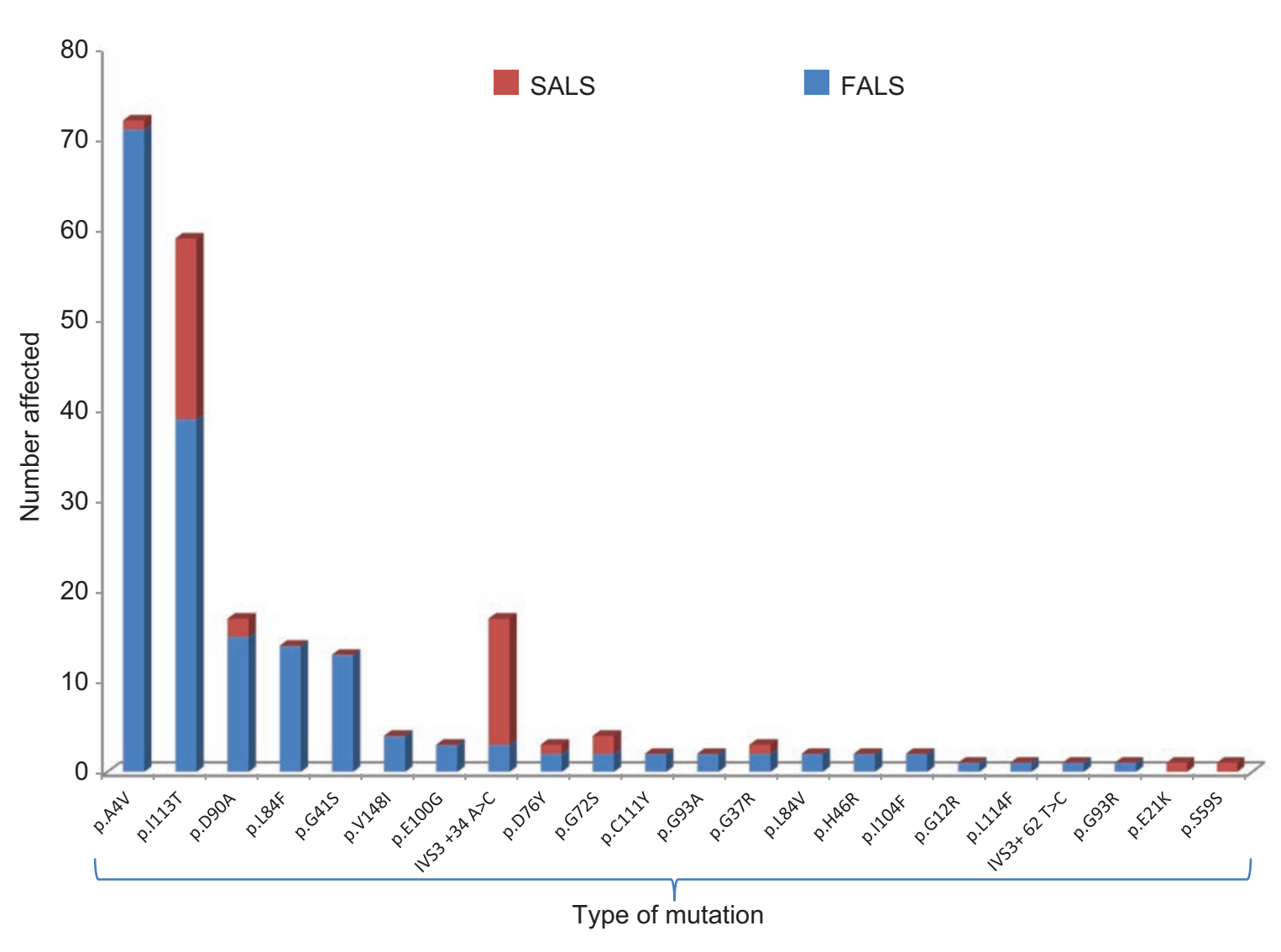

Figure 1. Proportion of mutations found in the SOD1 gene in patients with amyotrophic lateral sclerosis type 1. SALS = sporadic amyotrophic lateral sclerosis, FALS = familial amyotrophic lateral sclerosis.

population, one case of FALS was found to bear the heterozygous mutation p.L106, whose clinical presentation was characterized by relatively early age of onset, and bulbar and spinal involvement. ${ }^{25}$ SOD1 pathogenic mechanism in neuronal death varies; lines of evidence suggest poor protein folding. p.G10R mutation docking showed strong destabilization, which influences the strength of the dimer interface, generating toxic intracellular aggregates, which supports this theory. ${ }^{25}$

In a case report of two Italian patients with ALS, apparently sporadic, heterozygous for the p.D90A mutation in SOD1, one patient experienced early sensory involvement. ${ }^{26}$ In six families with ALS, the p.G41S mutation was detected by direct sequencing. Clinical pattern of these patients was characterized for the spinal appearance of upper and lower motor neurons with early involvement, the appearance of bulbar signs in one year and death a few months later; average age at onset was 49.3 years and average duration of the disease was 0.9 years; a common haplotype was found for carriers of the mutation, which demonstrates a founding effect in Italy. Indeed, the p.G41S mutation is constantly related to a severe, rapidly progressive phenotype. ${ }^{26}$
The following data were obtained from the aforementioned studies: total number of individuals affected by ALS was 2553, out of which 46 were FALS; in these cases, the most common mutations were p.I113T in $45.67 \%$ and IVS3+34 A>C in $30.44 \%$ (Fig. 1). In the FALS cases, the p.A4V, p.I113Y, p. D90A, p.L84F and p.G41S mutations were detected in $39.01,21.43,8.24,7.69$ and $7.14 \%$, respectively. Only two of the reviewed studies analyze the enzyme function with the mutations found in the affected population. ${ }^{22-23}$

\section{ALS is a complex disease}

Genetic studies show that ALS is a complex disease due to molecular heterogeneity, there are more than 23 responsible genes that have a direct effect on the phenotype, as described in Table 1. More than 140 different mutations distributed in the five exons and introns of the SOD1 gene have been reported, with p.A4V being the most common mutation in familial cases, while in sporadic cases it is the p.I113T mutation. ${ }^{10}$ This supports ALS high polygenic component, as well as its molecular and allelic heterogeneityz 
Disease presentation varies, with sporadic forms and familial variants that are transmitted with an autosomal dominant inheritance pattern; 6 -10 however, there are mutations that are transmitted with a recessive pattern. ${ }^{12,26,27}$ Even 85 -year-old, completely asymptomatic individuals have been reported to be carriers of the $p$. D90A mutation, with this adding to the hypothesis on the existence of a complementary mechanism responsible for neurological damage in ALS. ${ }^{26}$

It should be noted that the phenotype can differ depending on the region of the gene the mutations affect. There is not a clear genotype-phenotype correlation, due to differences in the presentation between familial and sporadic cases, as well as in intra-familial cases with the same mutation, ${ }^{22-26}$ which is attributed to variable expressivity or to modifier genes. ${ }^{10}$

ALS has been postulated to be a conformational disease, since mutations in SOD1 lead to changes in the structure of the enzyme and affect its catalytic activity (activity lower than $50 \%$ ), as well as to haploinsufficiency. ${ }^{22-23}$ On the other hand, accumulation of this protein with folding defects is related to mutations, which translates into gain-of-function with a toxic effect, known as negative dominant effect. ${ }^{26-27}$

Studies of targeted mutagenesis analyzing haploinsufficiency and the negative dominant effect are limited; in future works, it will be important to investigate them in order to identify the clinical effect of the amino acid change in the structure of the active site, the allosteric region and other SOD1 functional domains.

\section{Advances in ALS genetics}

Through new generation sequencing, $20 \%$ of familial cases were found in the French population, with a frequency of $50 \%$ for SOD 1 mutations, ${ }^{28}$ while in the English population the following mutations were found: p.C256G, p.G229T, p.A272C, p.A305G, p.C310T, p. G335A p.T341C and p.A403G. ${ }^{29}$ Recently, a new c.791A> G mutation was found in the SETX gene in a woman with ALs of Hungarian ancestry. ${ }^{30}$ In a population with that same ancestry, new mutations in the SOD1 gene have been reported in sporadic cases, including p.K91R/X, p.V14M, p.D90A, p.L144F and p.L91R/X8 ${ }^{31}$ Abnormal expansion of (GGGGCC)n of the C9ORF72 gene has also been found in up to $30 \%$ of SALS cases. ${ }^{31-32}$ The SOD1 and C9orf72 genes have the most important contribution in the pathogenesis of the disease. Currently, the new targets in ALS therapy are focused on protein homeostasis disruption, alterations in the biology of proteins that bind to RNA, as well as cytoskeleton dynamics defects. ${ }^{33}$

\section{Frontiers in ALS research}

The new challenges in the study of ALS are the effect of epigenetic modifications, which might shed light on the age of onset, familial presentation or severity; to facilitate the identification of efficacious therapies, early diagnosis and potential therapeutic interventions ate early stages. ${ }^{34}$ In Latin America, there is no research with information on ALS genetics. At the immune system level, the role of 19 cytokines has been explored including adipsin, adiponectin, IL-4 and IL-6 in relation to clinical severity and disease duration. Adipsin Wwas found to be elevated in cerebrospinal fluid; adiponectin showed a tendency towards higher concentrations ${ }^{35}-36$ Certainly, more epidemiological studies on these interleukins are necessary in order to establish their prognostic value. This evidence may suggest that variants in the genes that code for these proteins can modify ALS clinical expression. Relevant clinical studies include a report of four cases of juvenile familial ALSand prolonged survival. ${ }^{37-39}$ Recently, our working group reported a case of ALS in Mexico, which was positive for a mutation in the MT-CYTB gene. ${ }^{40}$

\section{Conclusions}

ALS is a complex genetic disease, which is reflected on its different inheritance patterns, mutational component, high penetrance, variable age of onset, anç simultaneously-altered multiple metabolic pathways in patients with this disease. On the other hand, mुost mutations found in SOD1 are mainly responsible for FALS and one third of SALS cases. There are other genes that should be explored as a cause, especially in FALS: C9orf72 and SETX. At the clinical level in Mexico, proinflammatory cytokines could be prognestic markers, although it will be necessary to validate them.

\section{Conflict of interest}

There were no conflicts of interest by the authors.

\section{Acknowledgements}

To Conacyt, for the national sabbatical grant stowed to Dr. Sergio A. Ramírez García, from Universidad de la Sierra Sur. 


\section{References}

1. Woolley SC, Rush BK. Considerations for clinical neuropsychological evaluation in amyotrophic lateral sclerosis. Arch Clin Neuropsychol. 2017;32:906-916

2. Couratier P, Marin B, Lautrette G, Nicol M, Preux PM. Epidemiology, clinical spectrum of ALS and differential diagnoses. Presse Med. 2014; $43: 538-548$

3. Volk AE, Weishaupt JH, Andersen PM, Ludolph AC, Kubisch C. Current knowledge and recent insights into the genetic basis of amyotrophic lateral sclerosis. Med Genet. 2018;30:252-258.

4. Rohrer JD, Isaacs AM, Mizielinska S, Mead S, Lashley T, Wray S, et al C9orf72 expansions in frontotemporal dementia and amyotrophic lateral sclerosis. Lancet Neurol. 2015;14:291-301.

5. Bunton-Stasyshyn RK, Saccon RA, Fratta P, Fisher EM. SOD1 function and its implications for amyotrophic lateral sclerosis pathology: new and renascent themes. Neuroscientist. 2015;21:519-529.

6. Jones CT, Brock DJ, Chancellor AM, Warlow CP, Swingler RJ. Cu/Zn superoxide dismutase (SOD1) mutations and sporadic amyotrophic lateral sclerosis. Lancet. 1993;342:1050-1051.

7. Schmitt ND, Agar JN. Parsing disease-relevant protein modifications from epiphenomena: perspective on the structural basis of SOD1-mediated ALS. J Mass Spectrom. 2017;52:480-491.

8. Kikugawa $K$, Nakano R, Inuzuka T, Kokubo Y, Narita $Y$, Kuzuhara S, et al. A missense mutation in the SOD1 gene in patients with amyotrophic lateral sclerosis from the Kii Peninsula and its vicinity, Japan. Neurogenetics. 1997;1:113-115

9. Zhang CC, Zhu JX, Wan Y, Tan L, Wang HF, Yu JT, Tan L. Meta-analysis of the association between variants in MAPT and neurodegenerative diseases. Oncotarget. 2017;8:44994-45007.

10. Morello G, Spampinato AG, Cavallaro S. molecular taxonomy of sporadic amyotrophic lateral sclerosis using disease-associated genes. Front Neurol. 2017;8:152.

11. Battistini S, Giannini F, Greco G, Bibbò G, Ferrera L, Marini V, et al. SOD1 mutations in amyotrophic lateral sclerosis. Results from a multicenter Italian study. J Neurol. 2005;252:782-788.

12. Chiò A, Mazzini L, D'Alfonso S, Corrado L, Canosa A, Moglia C, et al The multistep hypothesis of ALS revisited: the role of genetic mutations. Neurology. 2018;91:e635-e642.

13. Peters OM, Ghasemi M, Brown RH. Emerging mechanisms of molecular pathology in ALS. J Clin Invest. 2015;125:1767-1779.

14. Salem K, McCormick ML, Wendlandt E, Zhan F, Goel A. Copperzinc superoxide dismutase-mediated redox regulation of bortezomib resistance in multiple myeloma. Redox Biol. 2015;4:23-33.

15. Venkataramani V, Doeppner TR, Willkommen D, Cahill CM, Xin Y, Ye G, et al. Manganese causes neurotoxic iron accumulation via translationa repression of Amyloid precursor protein and H-Ferritin. J Neurochem. 2018;147:831-848.

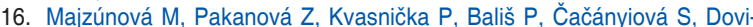
nová I. Age-dependent redox status in the brain stem of NO-deficient hypertensive rats. J Biomed Sci. 2017;24:72.

17. Popović-Bijelić A, Mojović M, Stamenković S, Jovanović M, Selaković V, Andjus $\mathrm{P}$, et al. Iron-sulfur cluster damage by the superoxide radical in neural tissues of the SOD1(G93A) ALS rat model. Free Radic Biol Med. 2016:96:313-322

18. D'Ambrosi N, Cozzolino M, Carrì MT. Neuroinflammation in Amyotrophic lateral sclerosis: role of redox (dys) regulation. Antioxid Redox Signal. 2018;29:15-36

19. Pardo CA, Xu Z, Borchelt DR, Price DL, Sisodia SS, Cleveland DW. Superoxide dismutase is an abundant component in cell bodies, dendrites, and axons of motor neurons and in a subset of other neurons. Proc Natl Acad Sci U S A. 1995:92:954-958.

20. Carocci A, Catalano A, Sinicropi MS, Genchi G. Oxidative stress and neurodegeneration: the involvement of iron. Biometals. 2018;31:715-735.
21. Andersen PM, Sims KB, Xin WW, Kiely R, O'Neill G, Ravits J,et al. Sixteen novel mutations in the $\mathrm{Cu} / \mathrm{Zn}$ superoxide dismutase gene in amyotrophic lateral sclerosis: a decade of discoveries, defects and disputes. Amyotroph Lateral Scler Other Motor Neuron Disord. 2003:4:62-73.

22. Deng HX, Hentati A, Tainer JA, Iqbal Z, Cayabyab A, Hung WY, e tet Amyotrophic lateral sclerosis and structural defects in $\mathrm{Cu}, \mathrm{Zn}$ superoxide dismutase. Science. 1993;261:1047-1051.

23. Abe K, Aoki M, Ikeda M, Watanabe M, Hirai S, Itoyama $Y$, et al. Clinical characteristics of familial amyotrophic lateral sclerosis with Cu/Zn superoxide dismutase gene mutations. J Neurol Sci. 1996;136:108-116.

24. Eisen A, Mezei MM, Stewart HG, Fabros M, Gibson G, Andersen PM, et al. SOD1 gene mutations in ALS patients from British Columbia; $\mathrm{Ca}$ nada: clinical features, neurophysiology and ethical issues in management. Amyotroph Lateral Scler. 2008:9:108-119.

25. Alavi A, Nafissi S, Rohani M, Zamani B, Sedighi B, Shamshiri H, et. Genetic analysis and SOD1 mutation screening in Iranian amyotrophic lateral sclerosis patients. Neurobiol Aging. 2013;34:1516.e1-8. 으

26. Battistini S, Ricci C, Giannini F, Calzavara S, Greco G, Del Corona A et al. G41S SOD1 mutation: a common ancestor for six ALS Italian families with an aggressive phenotype. Amyotroph Lateral Scler. 2010:11:210-215

27. Alemasov NA, Ivanisenko NV, Taneja B, Taneja V, Ramachandran S Ivanisenko VA. Improved regression model to predict an impact of SOD1 mutations on ALS patients survival time based on analysis of hydrogen bond stability. J Mol Graph Model. 2018;86:247-255.

28. Corcia P, Couratier P, Blasco H, Andres CR, Beltran S, Meininger $V_{\text {E et al }}$. Genetics of amyotrophic lateral sclerosis. Rev Neurol (Paris). 2017:173:254-262.

29. Morgan S, Shatunov A, Sproviero W, Jones AR, Shoai M, Hughes D, et al. A comprehensive analysis of rare genetic variation in amyotrophic lateral sclerosis in the UK. Brain. 2017:140:1611-1618.

30. Tripolszki K, Török D, Goudenège D, Farkas K, Sulák A, Török N, et al. High-throughput sequencing revealed a novel SETX mutation in a Hungarian patient withamyotrophic lateral sclerosis. Brain Behav. 2017:7:e00669.

31. Tripolszki K, Csányi B, Nagy D, Ratti A, Tiloca C, Silani V, et al. Genetic analysis of the SOD1 and C9ORF72 genes in Hungarian patients with amyotrophic lateral sclerosis. Neurobiol Aging. 2017;195:e1-195.e5

32. Martin S, Al-Khleifat A, Al-Chalabi A. What causes amyotrophic tateral sclerosis? F1000Res. 2017;8:371

33. Ghasemi M, Brown RH. Genetics of amyotrophic lateral sclerosis Cold Spring Harb Perspect Med. 2018;8:pii.

34. Jiménez-Pacheco A, Franco JM, López S, Gómez-Zumaquero JMī̄Magdalena-Leal-Lasarte M, Caballero-Hernández DE, et al. Epigenetic mechanisms of gene regulation in amyotrophic lateral sclerosis. Adv Exp Med Biol. 2017:978:255-275

35. Martínez HR, Escamilla CE, Camara CR, González MT, Tenorio JM, Hernández M. CSF concentrations of adipsin and adiponectin in patients withamyotrophic lateral sclerosis. Acta Neurol Belg. 2017;117(4):879.883.

36. Martínez HR, Escamilla CE, TenorioJM, Gómez D, Jaime JC OIguín-LA, et al. Altered CSF cytokine network in amyotrophic lateralscle-

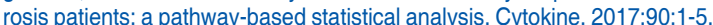

37. Martínez HR, Parada JD, Meza ME, González MT, Moreno CJ. Esclerosis lateral amiotrófica. Contribución de la neurología mexicana de9998 a 2014. Rev Mex Neuroci. 2014;15:355-362.

38. Arriada N, Ríos C, Otero-Siliceo E, Corona-Vázquez T. ALS in a Secluded region in Mexico possibly related to lead toxicity. Arch Neurocieäces. 2000;5:2-5.

39. Bresch S, Delmont E, Soriani MH, Desnuelle C. Electrodiagnostic criteria for early diagnosis of bulbar-onset ALS: a comparison of El Escorial, revised El Escorial and Awaji algorithm. Rev Neurol (Paris). 2014;170:134-139.

40. Cervantes I, Ramírez S, García D. Amyotrophic lateral sclerosis positive for mutation in the CYTB gene and negative for SOD1 and ATXN2? Rev Fac Med. 2017;65:377-378. 